\title{
Development Practicum Tools on Doppler Effect Material to Improve Student Learning Outcomes
}

\author{
I Made Astra*, Lisda Hadiani Al Fitri \\ FMIPA Universitas Negeri Jakarta, Jl. Rawamangun Muka, RT.11/RW.14, Jakarta Timur 13220, Indonesia.
}

How to cite this paper: I Made Astra, Lisda Hadiani Al Fitri. (2020) Development Practicum Tools on Doppler Effect Material to Improve Student Learning Outcomes. Journal of Applied Mathematics and Computation, 4(4), 174-180.

DOI: $10.26855 /$ jamc.2020.12.008

Received: September 15, 2020

Accepted: October 26, 2020

Published: November 23, 2020

${ }^{*}$ Corresponding author: I Made Astra, FMIPA Universitas Negeri Jakarta, Jl. Rawamangun Muka, RT.11/RW.14, Jakarta Timur 13220, Indonesia.

Email: imadeastra@gmail.com

\begin{abstract}
Teaching standards in the context of the educational process not only convey subject matter, but they are also defined as the process of regulating the environment so that students learn. This environmental arrangement is a process of creating a good climate such as environmental regulation, provision of learning tools and resources that include teaching objectives, teaching materials, teaching and assessment learning methodologies that enable students to feel comfortable and enjoy learning so that they can develop optimally according to their interests and potential. This study aims to design and implement education that is more focused on mastering physical concepts that can support everyday life using existing media and facilities and is simple in the doppler effect material using borg gall development research. So, students can grow and improve good learning outcomes which are shown based on the results of calculations with a n-gain score of 0.68 and the practicum tool developed can be used for learning with an percentage of experts at $88.6 \%$.
\end{abstract}

\section{Keywords}

Development of Practicum tools, Doppler effects, Student learning outcomes

\section{Introduction}

The building process that encourages activities carried out by educational institutions to achieve the intended Education goals. Where the purpose of education is to deliver students and intellectuals, morals, social to live independently as individual and social beings [1].

Teaching in the context of the standard education process is not only applicable to material, but also the process used by students to learn. This environmental arrangement is something that creates a good environment such as environmental arrangement, provision of tools and resources that are used for purposes, basic materials, and learning methods that allow students to learn and look for the optimal [2]. But, in practice it does not always work well, because it often some obstacles. One of the uses of learning media is still relatively low. This caused a lack of facilities at the school based on interviews. However, students' physics learning outcomes are not optimal.

Student learning outcomes are one of the most important things in the learning process. High and low student learning outcomes are tools to who find out or never learn. Even so, daily activities still need media to help improve student learning outcomes. One of them, it can use practicum tools. But, in fact, availability of practicum tools is still lacking, including the Doppler effect in Depok, Tangerang and Bekasi in 38 schools. Learning outcomes obtained by students have not been maximized in 6 schools out of 480 students. Students just only want to memorize formulas and they do not know the application of the Doppler effect material. The lesson teachers often use power points of $81 \%$, whiteboard $76.2 \%$ and the use of practicum tools is only $28.6 \%$. In the Doppler effect material, learning is carried out only in textbooks. 


\section{Methodolgy}

The Doppler effect practicum tool developed is suitable for use as a learning medium. Development of practicum tools developed for the Doppler effect material can help improve student learning outcomes.

\subsection{Characteristics of a Developed Model}

The learning media developed in the form of a Doppler effect device using hanphone carried by a car with a speed that can be changed three times and in use it can be carried out with different direction conditions using a sample of research students of Senior High School 6 DEPOK.

\subsection{Research Design}

The research method used is a development research method with Borg and Gall design model. The stages carried out consisted of the research stage and information gathering with observation and literature study, the planning stage to make the instructional media design developed, making the instrument lattice and arranging instruments, the stage of developing a preliminary form of the product by making the Doppler effect learning media, the field test preparation stage carried out validation by expert material and learning media lecturers, major product revisions conducted revisions made by experts, main field testing phase conducted small group trials of 1-3 schools with 6-12 students, implementation stage of product evaluation revision and media revision based on test results try a small group, the operational field test phase by conducting a large group trial with 30-100 students [3].

The implementation of trials through observation and learning outcomes tests using the pre-test and post-test. The final product revision stage where the revision is based on the results of large group trials to determine the feasibility of learning media on the Doppler effect material, so that it can be used in learning activities to improve student learning outcomes, and the stages of dissemination and implementation as product reporting at professional meetings and journals.

The following Model Planning Chart:

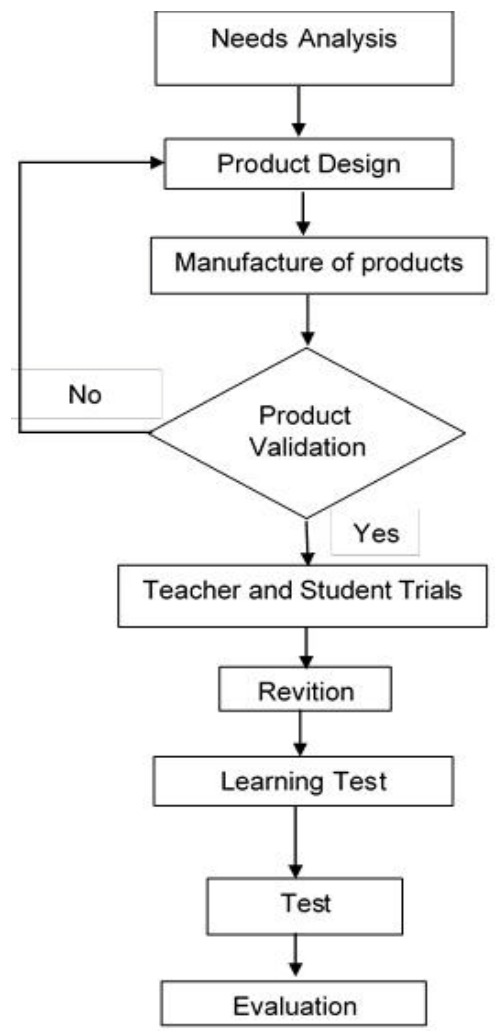

Learning media on the Doppler effect material was tried out to students of class XI Science at Senior High School 6 DEPOK as many as two classes. Students are given a pre-test and post-test to determine the improvement in learning outcomes before and after learning. To prove the effectiveness of Doppler effect learning media can use N-Gain analysis techniques and to determine the success of using percentages. 
The practical Doppler Effect design (Figure 1):

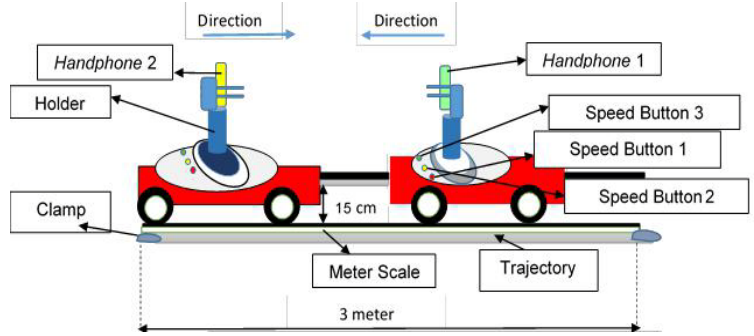

Figure 1. Practical Doppler Effect Design Tool.

\subsection{Data analysis}

Assessment of media and material expert instruments using Likert scale with levels 1-5. Then, instrument of post-test and pre-test in the form of multiple choices and the assessment validation with correlation biserial.

\subsection{Procedure}

The work steps for using the Doppler effect learning media are as follows:

1. Place both mobile phones on each holder

2. Put the two holders above each car

3. Turn on the sound on handphone 1 as a sound source that has been known to have a large frequency using the Sonic Application

4. Turn on the Doppler Effect Application on handphone 2 as the listener frequency

5. Select and press the speed found in each car

6. The movement of the car using the remote control in the specified direction

7. See the frequency, distance, time and speed obtained by reading the existing scale

\section{Result and Discussion}

The purpose of developing practicum tools developed so that they can be used as learning media and help improve student learning outcomes. Where students do not only see simulations through videos, books and phenomena that are around. However, students can try to practice using simple media in learning activities on the Doppler effect material. The development of this practicum tool uses a mobile phone and its application that can be driven by a car that has three speeds and it controlled by a remote control. The cellphone can be used as a source of sound and listeners use application are sonic and Doppler effects.

In this case, students can choose the speed that is available when they want to do the practicum and the measurement of the speed is seen on a speedometer. The frequency of the desired sound source can also be changed by replacing a number and the audible frequency can be captured by the Doppler effect application. The results of the data obtained are attached.

The trial of the feasibility of the practicum tool on the Doppler effect material was carried out by validation to the material and media experts. The description of the results of expert material validation tests. Validation tests by material experts were conducted at Jakarta State University involving two physics lecturers. This validation aims to determine the quality of practicum tools that have been developed in terms of material. This assessment is given through the material expert validation test sheet. Data results have shown quality content $86 \%$, accuracy $88 \%$, and presentation $85 \%$. Based on the data that, an average percentage of overall aspects is $86 \%$. This shows that the practicum tools developed are very worthy of seeing the quality, accuracy and presentation of the Doppler effect material. The advice given by material experts are the speed measured by the tool must be calibrated.

Description of the results of the media expert validation test. Validation test by media experts was conducted to determine the quality and feasibility of practicum tools as media. Media experts involved were lecturers for two people. Assessment is given through the media expert validation test sheet. Data results shown display quality $88 \%$, media design $85 \%$, and presentation $100 \%$. Based on the data that, the average percentage of all aspects is $91 \%$. This shows that the practicum tools are developed very worthy of seeing the quality of the display, the design of the media, and the presentation of the Doppler effect material. The following inputs and suggestions provided by experts, among others: clear radiance, it will be better to change the speed of the car can be set via the remote control.

Based on the results of the validation carried out in terms of material and media shows that the practicum tools developed are suitable to be used as learning media in the classroom regarding the Doppler effect material. The practicum tool 
was then piloted to school in the $11^{\text {th }}$ grade students of Science at Senior High School 6 DEPOK.

This field trial aims to determine the effectiveness of practicum tools developed whether it can help improve student learning outcomes or not. This assessment is done by giving a pre-test and post-test to students who take lessons using the media (practicum tools) and it is not using the media. Improved learning outcomes before and after learning can be seen from the results of n-gain analysis with a score of 0.6806 which means there is an increase in learning outcomes in the medium category.

The development of the Doppler effect practicum tool is the development of the previous practicum tool. This tool is made with simple media using technology tools (mobile phones) along with applications that can be driven by a car with three types of speed and can be controlled by a remote control.

Based on the results of the validation by experts, it shows that the practicum tool is suitable to be used as a learning media in the classroom. This is shown from the results of the validation of material and media experts with an overall percentage of $88.6 \%$.

In terms of material experts, the Doppler effect practicum tool has the value of several aspects consisting of $86 \%$ content quality, $88 \%$ accuracy, and $85 \%$ presentation. In terms of media experts, the practicum tool has a display quality of $88 \%$, media design $85 \%$, and presentation of $100 \%$.

The practicum tool that was developed after being validated, it was tried out to students of class XI of SMAN 6 DEPOK to find out whether the tool could help improve student learning outcomes or not. The results show that there is an increase in learning outcomes seen from the N-gain score of 0.68 which means that there is an increase in learning outcomes in the medium category. Based on the results of the $t$ test obtained $t$ hit $=8.63$ with $t$ table $=2.60$, which shows $\mathrm{t}$ hit $>\mathrm{t}$ table then the use of the practicum tool Doppler effect can help improve student learning outcomes.

The instrument used before being tested on students, firstly it tested for validity and reliability. Thus, it can determine the instrument can be trusted or not. This shows that the pre-test and post-test summary instruments of 20 items contained 2 invalid questions and the reliability of the questions was 0.60 which meant that the reliability level was in the strong category. For the level of difficulty there are easy, medium and difficult questions and the difference in the questions is sufficient, good, and very good. For the psychomotor instrument (skills) students also consisted of 14 items, there were 2 invalid items. The measurement of psychomotor instruments uses a Likert scale with a scale of 1-5.

During the activity, students become more active and interactive in trying the practicum tool. Students have the desire to learn to know the process of what will happen in it. Students communicate with the group to discuss together, they are working on the worksheets that it have been given and students are easily to understand about the material being taught based on the results of the interview. This is in accordance with Zainal and Sudjana, that the use of media (practicum tools) is used as a tool to channel messages, stimulate the learning process and can attract students' attention that can foster motivation and desire to learn [4]. Students are not become bored and teacher teaching methods are more varied.

The development of the Doppler effect practicum tool is also in accordance with the Subarnia research on the Development of Environmental Oriented Practicum Devices that Support Junior High School Natural Science Learning in accordance with the 2013 Curriculum that the practicum tools developed are able to support the science learning process to be more attractive with activities towards the utilization of $96.8 \%$ environmentally oriented practicum devices and help teacher in learning activities [5]. Research on Development of Resonance and Doppler Effect Practicum Tools Based on Soundcard PC/Laptop to Improve Physics Learning Motivation of High School Students by Caisar (2015) that resonance practicum tools and Doppler effects developed can increase the motivation to learn physics in high school students [6]. This study uses a car with one type of speed that can be driven by a sewing machine dynamo engine with the help of rope thread in unidirectional conditions. In the Doppler Effect Analysis study on the ITS-SAT communication system also shows that the Doppler shift effect has a significant influence on the picosatellite communication system for sending image information (helping to capture frequencies) [7]. Research on Radio Doppler Method for Measuring RX200 Rocket Speed by Wahyu which shows that the Doppler method is easy to implement to measure position, and also the frequency measurement of Doppler effects can be done directly, so that rocket speed measurement can also be done more accurately than the measurement results of radar transponders [8].

Based on the above research, the development of this practicum tool has the advantages of previous research (Caisar), among others: the device can be moved with a remote control so that it can be conditioned in various directions as desired, frequency selection can be changed by replacing numbers without we need to measure the sound frequency that appears first, the driving car has three types of speed and it can be changed also by rotating the potentiometer beside the button both forward and backward, measuring speed (average and constant), time, distance can be seen on the speedometer screen, practicum tools are easy to carry around and used for calibration, along with listener frequency measurements and source frequencies can use the application on the cellphone. The frequency of the listener uses the Doppler Effect application, the application can capture the frequency of the source provided. This practicum tool can also be used in GLB and GLBB practicums. However, the Doppler effect practicum tool has a drawbacks, the user must be able to 
control the car well (the car goes straight and it does not turn in the case of the Doppler effect).

The use of learning media is not only seen or judged from the sophistication of the media, but its function and role in helping to enhance the teaching process is very important. Practicum is one form to demonstrate the ability to master theoretical material in addition to training students' skills, perseverance, and discipline.

The Doppler effect experiment is done when the sound source is approaching and away from the listener. Thus, students can find out the frequency that is heard lower or higher and the change in the frequency of the relative motion between the source and listener is called the phenomenon of the Doppler effect. Students collect data with the group, then the results of the experiment can be calculated and it adjusted to the existing theory that when the sound source approaches the listener, the frequency heard by the listener is higher than the original frequency, and vice versa. So, students are not only smart at counting and memorizing, but he understands the concept of the Doppler effect material taught. The following product (Figure 2):

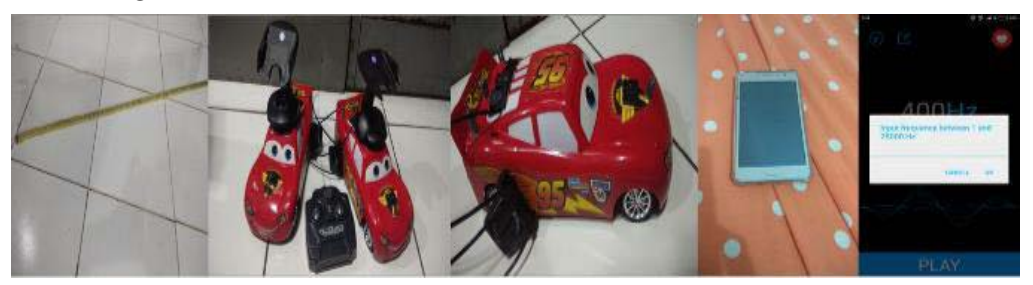

Figure 2. Product.

The results of the frequency:

Source and Listener are silent

\begin{tabular}{|c|c|c|c|c|c|c|c|c|c|c|}
\hline$t(s)$ & $V_{p}$ & $V_{s}$ & $f_{s}$ & $f p(H z)$ & Teorifp & $\begin{array}{c}\text { Frequency } \\
\text { Shift (\$6) }\end{array}$ & fs & $f_{p}(\mathrm{~Hz})$ & Teori Fp & $\begin{array}{c}\text { Frequency } \\
\text { Shift (\%) }\end{array}$ \\
\hline 0 & 0 & 0 & 500 & 501,28 & 500 & 0,26 & 600 & 600,034 & 600 & 0,005 \\
\hline 0,1 & 0 & 0 & 500 & 500,90 & 500 & 0,18 & 600 & 604,11 & 600 & 0,685 \\
\hline 0,2 & 0 & 0 & 500 & 501,13 & 500 & 0,23 & 600 & 604,11 & 600 & 0,685 \\
\hline 0,3 & 0 & 0 & 500 & 501,25 & 500 & 0,25 & 600 & 604,11 & 600 & 0,685 \\
\hline 0,4 & 0 & 0 & 500 & 501,25 & 500 & 0,25 & 600 & 603,972 & 600 & 0,662 \\
\hline 0,5 & 0 & 0 & 500 & 501,13 & 500 & 0,23 & 600 & 604,11 & 600 & 0,685 \\
\hline 0,6 & 0 & 0 & 500 & 501,13 & 500 & 0,23 & 600 & 604,179 & 600 & 0,6965 \\
\hline 0,7 & 0 & 0 & 500 & 501,13 & 500 & 0,23 & 600 & 604,11 & 600 & 0,685 \\
\hline 0,8 & 0 & 0 & 500 & 501,02 & 500 & 0,20 & 600 & 604,11 & 600 & 0,685 \\
\hline 0,9 & 0 & 0 & 500 & 501,02 & 500 & 0,20 & 600 & 604,11 & 600 & 0,685 \\
\hline 1 & 0 & 0 & 500 & 501,13 & 500 & 0,23 & 600 & 604,11 & 600 & 0,685 \\
\hline
\end{tabular}

Sources approach listeners

\begin{tabular}{|c|c|c|c|c|c|c|}
\hline \multicolumn{2}{|c|}{ Vs } & \multirow{2}{*}{$\mathbf{V p}$} & \multirow{2}{*}{ fs } & \multirow{2}{*}{ fp } & \multirow{2}{*}{ Teori fp } & \multirow{2}{*}{$\begin{array}{l}\text { Frequency } \\
\text { shift (\%) }\end{array}$} \\
\hline $\mathrm{km} / \mathrm{jam}$ & $\mathrm{m} / \mathbf{s}$ & & & & & \\
\hline 10,4 & 2,8 & 0 & 500 & 501 & $(340 /(340-2,8)) \times 500=504,15$ & 0,62 \\
\hline 16,5 & 4,6 & 0 & 500 & 502 & $(340 /(340-4)) \times 500=506,85$ & 0,95 \\
\hline 17,8 & 4,9 & 0 & 500 & 504 & $(340 /(340-4,9)) \times 500=507,31$ & 0,65 \\
\hline
\end{tabular}

Source away from listeners

\begin{tabular}{|c|c|c|c|c|c|c|}
\hline \multirow{2}{*}{ Vs } & \multicolumn{2}{|c|}{$V_{p}$} & \multirow{2}{*}{ fs } & \multirow{2}{*}{$f p$} & \multirow{2}{*}{ Teori fp } & \multirow{2}{*}{$\begin{array}{l}\text { Frequency } \\
\text { Shift }(\%)\end{array}$} \\
\hline & $\mathrm{km} / \mathrm{jam}$ & $\mathbf{m} / \mathbf{s}$ & & & & \\
\hline 0 & 14,1 & 3,916667 & 400 & 398 & $((340 / 340+3,9) \times 400=395,4$ & 0,6 \\
\hline 0 & 14,6 & 4,055556 & 400 & 398 & $((340 / 340+4) \times 400=395,3$ & 0,7 \\
\hline 0 & 20,7 & 5,75 & 400 & 397 & $((340 / 340+5,7) \times 400=393,4$ & 0,9 \\
\hline
\end{tabular}


So, it looks at the graph (Figure 3 and Figure 4):

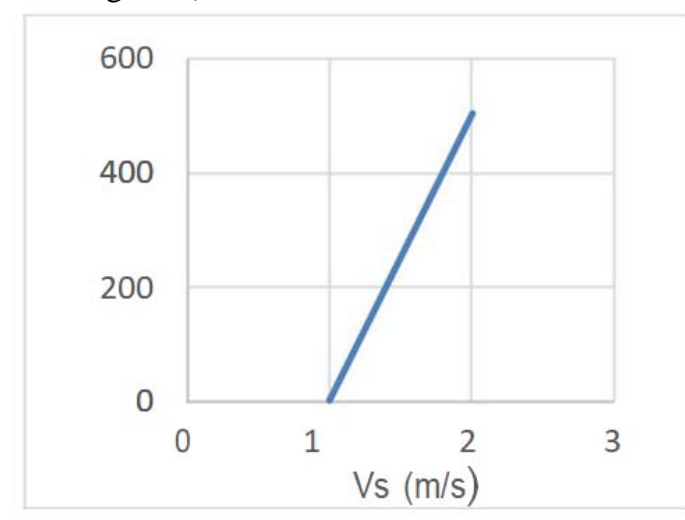

Figure 3. Graph source close to the silent listener.

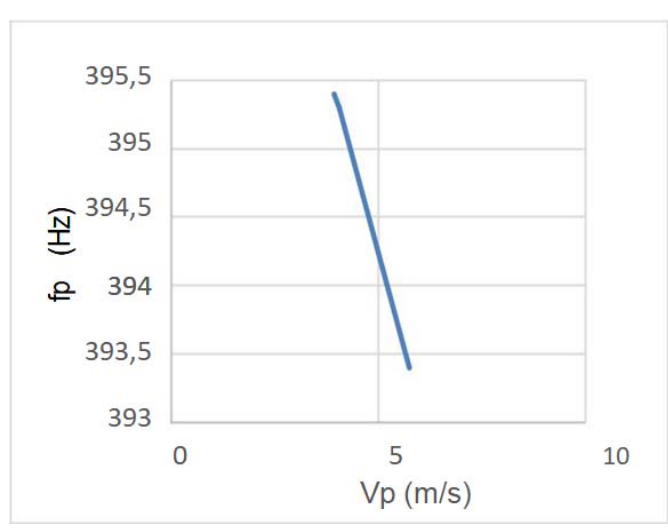

Figure 4. Graph silent listener away from the source.

Based on the graph above, shows that when the source approaches the silent listener, fp > fs, and when the source is away from the silent listener fs $>$ fp. The calibration results data as follows:

\begin{tabular}{cccccc}
\hline $\mathbf{s}$ & $\mathbf{t}$ & \multicolumn{2}{c}{$\boldsymbol{v}_{\text {Speedometer }}$} & $\boldsymbol{v}_{\text {hitung }}$ & Frequency \\
$\mathrm{cm}$ & sekon & $\mathrm{km} / \mathrm{jam}$ & $\mathrm{m} / \mathrm{s}$ & $\mathrm{m} / \mathrm{s}$ & shift (\%) \\
\hline 150 & 2.22 & 23.3 & 6.47 & 6.75 & 4.39 \\
170 & 2.32 & 26.8 & 7.44 & 7.32 & 1.56 \\
180 & 2.5 & 25.5 & 7.08 & 7,20 & 1.64 \\
180 & 2.78 & 23.5 & 6.52 & 6.47 & 0.81 \\
200 & 3.06 & 24.2 & 6.72 & 6.53 & 2.77 \\
200 & 3.16 & 21.6 & 6.00 & 6.32 & 5.48 \\
200 & 3.34 & 22.8 & 6.33 & 5.98 & 5.45 \\
\hline
\end{tabular}

In this case, the teacher can not only use sophisticated tools in learning activities, but it can design and carry out education, so that is more focused on mastering the concepts of physics that support everyday life using media and simple facilities being around. Thus, such learning can help introduce more students to natural phenomena and the surrounding environment.

\section{Conclusion}

Based on the results of the study can be concluded are the practicum tool developed is suitable for use as a learning medium with a percentage of $88.6 \%$ by experts dan the practical tools developed can help improve student learning out- 
comes with an $\mathrm{N}$-Gain score of 0.6806 in the medium category.

\section{Implications}

The researcher hopes that the practicum tools developed can be used as a learning media in class to help convey the concept of the Doppler effect material and learning to be fun.

\section{Acknowledgments}

The authors would like thank all those who have contributed to this research.

\section{References}

[1] Andang, M. (2010). Alat Ukur Kecepatan Fluida dengan Efek Doppler Menggunakan Mikrokontroller AT89S51. Kampus IST AKPRIND Yogyakarta.

[2] Harjalali. (2017). Startegi Guru dalam Membangun Lingkungan Belajar yang Kondusif: Studi Fenomenologi Pada Kelas-Kelas Sekolah Menengah Pertama DI Ponorogo. Universitas Negeri Malang.

[3] Tegeh, I. M. (2014). Model Penelitian Pengembangan. Jakarta: Graha Ilmu.

[4] Zainal. (2017). Model-Model, Media, dan Strategi Pembelajaran Kontekstual. Jakarta: PT YRAMA WIDYA.

[5] Subarnia, I. D. (2015). Jurnal Pengembangan Perangkat Praktikum Berorientasi Lingkungan Penunjang Pembelajaran IPA SMP sesuai Kurikulum 2013 di Singaraja.

[6] Caisar, M. (2015). Pengembangan Alat Praktikum Resonansi dan Efek Doppler Berbasis Soundcard PC/Laptop Untuk Meningkatkan Motivasi Belajar Fisika Siswa SMA . Universitas Negeri Jakarta.

[7] Paulus, A. (2013). Analisis Efek Doppler pada Sistem Komunikasi ITS-SAT.

[8] Widada, Wahyu. (2012). Jurnal Metode Doppler Radio Untuk Mengukur Kecepatan Roket RX200. Jakarta: LAPAN. 